\title{
Report on the Human Remains Found at Gezer, 1902-3
}

\section{A. Macalister}

To cite this article: A. Macalister (1903) Report on the Human Remains Found at Gezer, 1902-3, Palestine Exploration Quarterly, 35:4, 322-326, DOI: 10.1179/peq.1903.35.4.322

To link to this article: http://dx.doi.org/10.1179/peq.1903.35.4.322

曲 Published online: 20 Nov 2013.

Submit your article to this journal $\pi$

Џ Article views: 8

Q View related articles $\sqsubset$ 
round it. It was found to be filled with large stones, many of them drafted and moulded-the cast-away materials of some building which had apparently been pulled down. Probably they came from the large square building already mentioned, or from one of the buildings in an upper stratum.

\section{ADDENDA.}

April, 1903.-Page 118, line 13 below the stave of music, for "concave" read "convex."

Page 124, line 4 from end, the Egyptian sign is misprinted $\mathrm{A}$; also on page 125, line 2, after

July, 1903.-Pages 209, 210. The objects shown in Figs. 8 and 10 are not bone, but ivory.

Pages 216-218. I find that I was misinformed as to the names of some of the water-sources referred to in this section, though the argument is not affected thereby. The well called Bîr et-Tirâsheh should really be named Bîr el-Balad; the name in the text, which ought to be spelt Bîr eț-Tayâsheh (without $r$ ), properly belongs to a more distant well, north of Bîr el-Lusiyeh, and not entering into the discussion.

\section{REPORT ON THE HUMAN REIIAINS FOUND AT GEZER, 1902-3.}

By Professor A. Macalister, M.D., F.R.S.

Portions of human skeletons have been obtained from four localities :-

(1) From the deepest stratum, lying immediately upon the rock.

(2) From the second stratum.

(3) From the area of the great standing stones on the horizon of their bases.

(4) From a cistern on the east side of the "High Place."

(1) Unfortunately the bones found in the deepest stratum were fragmentary. They were parts of two skulls, both unusually thick; with them were fragments of limb bones too small to indicate the exact stature, but enough to show that the individuals were under 
the middle height. The skulls seemed to have been moderately broad, but were too incomplete for measurement.

(2) From the second stratum came an anomalously-shaped female skull, spheno-cephalic, with a length-breadth index of 78 , flattened at the lambdoid region and somewhat flat-topped. It belonged to a woman probably over 45 years of age. There were no whole limb bones with it, only some broken fragments.

(3) From the temple area the skull was a fairly capacious wellformed male skull, which in all characters was comparable with those of the next group.

(4) The remains of 18 individuals were found in the cistern; of these 14 were men, two were women, one a child of about 12 years, and one an infant. In this cistern the bodies were not disposed in any order. They were found, not on the rock floor, as in the cistern described last year, but upon a thick layer of clay silt about $1 \frac{1}{2}$ feet deep. They mostly lay directly under the mouth of the cistern, and many large stones had fallen in with and over them. Above the stony layer about 3 feet of earth had been washed in at a subsequent period. The bones of the skeletons were not found together, but there was no sign of artificial dismemberment. It seemed rather as if they had lain in the water of the cistern and had become separated in the ordinary course of decomposition, becoming washed asunder in the course of the periodic inflow of water during the rains. In character the skulls closely resembled those in the last burial cistern. The male skulls were ellipsoidal, capacious, some a short broad ellipse in norma verticalis, others a little narrower. The indexes of the three widest were 76.5 , and those of the others ranged from 73 to 75 . The female skulls are somewhat ovoidal with indexes of 76 . In all, the foreheads are rounded, most prominent medially at the metopion, the brow ridges are moderate, the occipital regions are generally slightly flattened and the sides steep.

In all those in which the facial bones have remained the facial region was elongated and narrow, though wide at the cheekbones, the palate rounded, the teeth large, and in those of advanced age much worn, the lower jaw oblique, with somewhat receding chin. The orbits were wide and the nasal region long and narrow, the nasal bones being fairly high-pitched.

The long bones, though in bad condition, were sufficiently sound to be measured when exposed in situ before being lifted. From 
these we obtained definite data as to stature. One male skeleton must have been a few $\mathrm{mm}$. over 6 feet in height, but the others were much shorter and ranged from 5 feet 4 inches to 5 feet 9 inches. The females were about 5 feet 2 inches and 5 feet 3 inches respectively. None of the femora were pilastered, but two were platymeric. The neck angle of the femur was very variable in both sexes. The tibiæ of six of the skeletons showed the small flexion facets due to extreme bending of the ankle, and extensions of the flexion surfaces were well marked in the knee and hip joints. None of the tibiæ were platycnemic.

The race to which these bones belonged must have been in almost all physical characters identical with that represented by the fellahîn who are the present inhabitants of this portion of the land. I have been able to make a considerable number of observations on the physical characters of the fellahin of this district, and have been very much struck with the singularly close conformity between them and their ancient Semitic predecessors. Among the workpeople on the tell and the inhabitants of the neighbouring villages both facial and other characters closely correspond to those of the Amorites. The average male stature here is between 5 feet 6 inches and 5 feet $7 \frac{1}{2}$ inches, but $I$ have seen three men over 6 feet in height. The female stature ranges from 4 feet 11 inches to 5 feet 6 inches. The heads of the men are almost all dolichellipsoid, with rounded foreheads only moderately prominent at the frontal eminences, but bulging medially. The brows are fairly heavy, often rising at their lateral end, and scarcely ever synophryous; the noses for the most part prominent and fairly straight, with large cartilages and alæ, but with narrow nostrils. In a few the nose is slightly aquiline, very rarely concave. The inter-orbital width is considerable, and the columna nasi wide. The malar regions are moderately prominent, giving a width to the lower orbital region of the face. The chin is weak, tending to recede owing to the obliquity of the jaws; the lips fairly thick and often prominent; the eyes usually fairly large and prominent, with irides ranging in colour from yellow-brown to dark blackish brown. Facial hair is not very abundant or general, in colour ranging from dark brown to black; where there is a beard, it is short and curly.

There are, of course, a number of exceptions. One man from Zakarîyeh has peculiarly Mongolian features-a wide flat face, and 
oblique eyes with epicanthal folds. Two others have low-bridged noses, somewhat concave in outline. One especially has a deep fronto-nasal notch and a short nose very prominent at the tip.

The female faces are proportionally wider and shorter than the males. The head outlines are more ovate and more rounded in the occipital region. The foreheads are generally flatter, the noses seldom quite straight or high-bridged, usually flatter at the upper bony portion, and widening to the alar region. The nostrils are, in consequence, often more oblique than in the males. The chin is small and rounded, its apparent recession exaggerated by the habit of keeping the mouth open. The eyes have irides varying from very dark brown to black, but in two girls they are of a very light yellowish brown colour. I have not seen any blue eyes even in those with the fairest hair. The blackest eyes here are in some small women who may be of gipsy origin. The hair is usually dark brown or black, with a slight inclination to curl on each side of the forehead. In one, however, the hair is distinctly fair, and in another it is of a light chestnut brown colour. Well-formed, slender, aquiline noses and symmetrical features are the exception, the standard of good looks being distinctly lower among the females than among the males. The photographs ${ }^{1}$ taken represent very well the extreme ranges of characters met with, as well as the most prevailing types of face.

As the men often sit on the ground with knees and ankles acutely flexed, it is probable that they, like their Amorite prototypes, possess the flexion facets above mentioned in these joints, which are of the same nature as those described in the Panjabi by Professor Havelock Charles.

In the foot I note that in the majority the great toe is set straight on the metatarsal, not bent outwards in the way described as normal by Dr. Joseph Griffiths; in the males the second toe appears generally to be a little longer than the first, but this is not the case in the females. The general physique of the Palestinian fellahin seems in all respects superior to that of the Egyptian. This is especially marked in the muscular development of the shoulders and of the calves of the legs.

[P.S.-Just as this report was finished a number of skeletons have been found in another cemetery near the temenos described

1 [A number of the most characteristic are held over until the final Memoir.-ED.] 
in an earlier report. The bones are in bad condition, but as far as I have been able to examine and measure them, they are quite comparable with those above described, and seem to belong to the same Semitic race.]

\section{THE TOMB OF NICANOR OF ALEXANDRIA. ${ }^{1}$}

By Miss Gladys Dickson.

AT the north end of the Mount of Olives, beside the carriage road on the east side of the road in the field belonging to Mr. Gray Hill and adjoining his house on the north, an interesting tomb has recently been opened.

The tomb consists of four independent groups of chambers (in this description numbered in order I to IV from north to south), ranged round an entrance vestibule.

The vestibule is open, and possibly had pillars in front (like Mughiret el-'Anab and the "Tombs of the Kings"), but this is uncertain, and requires excavation to determine. The roof, which is now broken down, was 9 feet 9 inches above the floor. The Chamber-groups I and III open off the vestibule by small doors on a level with the floor; II and IV by doors sunk below that level, at the ends of deep rectangular depressions.

Chamber-group $I$ consists of a single main chamber with four subsidiary chambers opening off it, the doorways to which are arched, surrounded by square reveals.

Chamber-group II is very elaborate. The central chamber is roofed with a barrel vault. This is the only chamber in the system with a raised bench running round the walls. This bench is $4 \frac{1}{2}$ inches high. The group is unfinished; on the south side of the sinking leading to the entrance from the vestibule, a doorway is blocked out; and in the north-east corner of the main chamber is a square sinking in the floor, with another blocked-out doorway at its east end. Round the main chamber are nine small doors, alternately round-headed in square reveals, and square-headed without reveals. These are lettered $a$ to $i$ on the plan, beginning at the right hand; $a$ is round-headed.

: See Quarterly Statement, January, p. 93, April, pp. 125-131. 